\title{
ANALISIS PENGGUNAAN DIKSI BERITA POLITIK HARIAN TRIBUN MEDAN (KAJIAN SEMANTIK LEKSIKAL)
}

\author{
Oleh \\ Entin Novita (entinnovita2@gmail.com) \\ Malan Lubis (Lbsmalan@gmail.com) \\ Universitas Negeri Medan
}

\begin{abstract}
Abstrak
Tujuan penelitian ini untuk mengetahui seberapa besar kesalahan penggunaan diksi dalam harian Tribun Medan terbitan Desember 2018. Penelitian ini menggunakan metode deskriptif kualitatif. Peneliti berperan sebagai instrumen utama dalam pengumpulan data dengan melakukan kegiatan pemaparan dan deskripsi terhadap objek penelitian. Data dikumpulkan dengan teknik baca, simak, dan catat kemudian memaparkan hasil analisis secara keseluruhan. Analisis data dalam penelitian ini merupakan analisis kesalahan penggunaan diksi secara deskriptif. Berdasarkan analisis kesalahan penggunaan diksi yang diperoleh hasil penelitian bahwa dalam harian Tribun Medan terbitan Desember 2018 terdapat kesalahan diksi dari segi konotasi, kesalahan diksi dari segi bersinonim. Kesalahan diksi dari segi pemakaian kata yang tidak ekonomis, dan kesalahan diksi dari segi pemakaian kata yang mubazir. Kesalahan penggunaan diksi yang paling banyak ditemukan di dalam harian Tribun Medan terbitan Desember 2018 kesalahan diksi dari segi bersinonim yaitu sebanyak 21 (56,75\%), kesalahan diksi dari segi konotasi yaitu sebanyak 16 (43,24\%). Kemudian kesalahan diksi dari segi pemakaian kata yang tidak ekonomis yaitu sebanyak 7 (87,5\%), kesalahan diksi dari segi pemakaian kata yang mubazir yaitu sebanyak $1(12,5 \%)$. Maka dapat disimpulkan bahwa kesalahan diksi yang sering ditemukan adalah ketidaktepatan dalam pemilihan kata, ketidaksesuaian atau kecocokan kata dalam kalimat, ketidaklangsungan atau tidak ekonomis kata yang dipilih dalam kalimat sehingga menjadi tidak efektif dan tidak efisien.
\end{abstract}

Kata Kunci: Analisis Penggunaan Diksi, Tribun Medan

\section{PENDAHULUAN}

Bahasa memegang peran penting dalam kehidupan masyarakat sebagai sarana untuk berkomunikasi. Dimana setiap anggota masyarakat dan komunitas tertentu selalu terlibat dalam komunikasi, baik yang bertindak sebagai komunikator (pembicara atau penulis) maupun sebagai komunikan (mitra-bicara, penyimak, atau pembaca). 
Bahasa adalah sistem lambang bunyi yang digunakan oleh masyarakat sebagai alat komunikasi.

Kridalaksana

(1984:28) mengatakan bahwa bahasa adalah sistem lambang bunyi yang arbiter yang dipergunakan oleh para anggota masyarakat untuk bekerjasama, berinteraksi dan mengidentifikasikan diri, percakapan (perkataan) yang baik, dan tingkah laku yang baik, sopan santun. Jadi bahasa adalah alat yang digunakan masyarakat untuk berinteraksi melalui perkataan. Salah satu media yang digunakan adalah surat kabar.

Bahasa pers merupakan satu ragam bahasa yang memiliki sifatsifat khas yaitu singkat, padat, sederhana, lancar, jelas, dan menarik. Hal ini disebabkan adanya sifat ekonomis yang dibutuhkan oleh surat kabar itu bukanlah hanya masyarakat dari kalangan masyarakat bawah. Bahasa yang rumit dan sulit akan menyulitkan pemahaman isi tulisan. Badudu (1985: 138).

$$
\text { Keraf }
$$

menjelaskan bahwa merupakan bentuk atau unit yang paling kecil dalam bahasa yang mengandung konsep atau gagasan. Kegiatan komunikasi kata-kata dijalinkan menjadi satu dalam suatu konstruksi yang lebih besar berdasarkan kaidah-kaidah yang ada dalam suatu bahasa, untuk menyatakan kata-kata yang digunakan untuk mengungkapkan ide atau gagasan, seorang penutur harus memperhatikan dalam ketepatan kata yang akan digunakan. Pilihan diksi mencakup pengertian kata-kata yang digunakan untuk menyampaikan ide atau gagasan. Tetapi pilihan kata tidak hanya mempersoalkan kata yang dipilih itu dapat diterima atau tidak merusak suasana yang ada. Kata merupakan alat menyalurkan gagasan, semakin banyak kata yang dikuasai seseorang, maka semakin banyak pula ide atau gagasan yang dikuasainya dan diungkapkan.

Semakin banyak kosakata yang dimiliki sehingga semakin memperlebar kebebasan seseorang untuk memilih kata dan berekspresi melalui kosakata tersebut untuk mewakili pemikirannya. Sedangkan 
ketepatan makna menuntut pula kesadaran untuk mengetahui bagaimana bentuk bahasa (kata) dan refrensinya. Sebab persoalan diksi tidak hanya menyangkut pemilihan kata secara tepat dan sesuai.Menurut Wibowo (dalam Silalahi, 2012: 2) dikatakan tepat agar gagasan sang penulis selaras dan dapat diwakili oleh kata-kata yang tepat, sehingga pengungkapan gagasan itu dianggap logis. Sedangkan dikatakan sesuai agar pilihan kata sang penulis selaras dengan konteks penulisan, nilainilai sosial, atau sesuai dengan dituasi yang dihadapi. Dengan menggunakan diksi yang tepat diharapkan isi pada berita dalam surat kabar penulis dapat diterima pembaca dapat memahami isinya dengan mudah.

\section{LANDASAN TEORI}

Beberapa butir perhatian dan persoalan berikut hendaknya diperhatikan setiap orang agar bisa mencapai ketepatan pilihan kata. Dalam Keraf (2001: 68) persyaratan ketepatan diksi adalah sebagai berikut:
1. Membedakan secara cermat denotasi dan konotasi.

2. Membedakan dengan cermat kata-kata yang hampir bersinonim.

3. Membedakan kata-kata yang mirip dalam ejaannya.

4. Hidarilah kata-kata ciptaan sendiri

5. Waspadalah terhadap penggunaan akhiran asing terutama kata-kata asing yang menggunakan akhiran asing tersebut.

6. Kata kerja menggunakan kata depan harus digunakan secara idiomatis.

7. Untuk menjamin ketepatan diksi, penulis atau pembaca harus membedakan kata umum dan kata khusus.

8. Mempergunakan kata-kata indria yang menunjukkan persepsi yang khsuus.

9. Memperhatiakan perubahan makna yang terjadi padakatakata yang sudah dikenal.

10. Memperhatikan kelangsungan pilihan kata.

\section{Kecermatan Pilihan Diksi}

Dalam pemakaian bahasa Indonesia ragam lisan fungsional 
memperhatikan adanya penggunaan struktur yang tidak ekonomis. Menurut Luimintatang (1988: 76) syarat-syarat kecermatan pilihan kata sebagai berikut :

\section{Pemakaian kata yang tidak ekonomis}

Pemakaian kata yang tidak ekonomis ditandai oleh pemakaian kata yang berpanjang-panjang atau berbelit-belit yang sebenarnya bisa dituturkan dengan tuturan yang singkat, jelas dan padat.

\section{Pemakaian kata yang mubazir}

Dalam bahasa Indonesia
ragam lisan fungsional juga
memperlihatkan struktur tuturan yang mengandung kemubaziran. Kemubaziran ini ditandai oleh pemakaian kata-kata yang diulangulang, kata tugas yang tidak diperlukan, pemakaian dua buah unsur yang berfungsi sebagai predikat kalimat, atau pemakaian kata bantu bilangan jamak yang diikuti oleh kata ulang pula.

\section{Pemakaian kata yang berbunga-bunga \\ Dalam penelitian juga memperlihatkan bahwa di dalam bahasa Indonesia ragam lisan}

fungsional tidak sedikit yang menampilkan tuturan yang sangat panjang, berbunga-bunga pula sehingga penalaran menjadi terabaikan. Gejala seperti ini cenderung ditemukan pada interaksi ketika berbicara.

\section{METODE PENELITIAN}

Metode penelitian adalah suatu cara dalam proses pemecahan masalah penelitian dengan mengumpulkan dan menganalisis data untuk mencapai tujuan yang diinginkan. Metode adalah cara atau langkah yang telah diatur dengan pemikiran baik untuk mencapai suatu maksud. Metode penelitian ditujukan untuk mencapai sasaran penelitian.

Berdasarkan masalah yang diajukan dalam penelitian ini yaitu tentang pendeskripsian bentuk penggunaan diksi, maka bentuk penelitian yang digunakan adalah penelitian kualitatif deskriptif. Bentuk penelitian ini mampu mendekripsikan secara teliti dan secara mendalam fakta-fakta yang diteliti, dalam hal ini bentuk diksi yang tidak tepat digunakan pada konteksnya. 
Alasan

peneliti

menggunakan metode ini sesuai dengan pendapat Lofland (dalam Moleong, 2012: 157) yang menyatakan bahwa "sumber data utama dalam penelitian kualitatif adalah kata-kata, dan tindakan selebihnya adalah tambahan seperti dokumen dan lain-lain.

\section{PEMBAHASAN}

\section{Kesalahan Penggunaan Diksi Berita Politik dalam Harian Tribun Medan dari Segi Ketepatan Diksi}

\section{a. Kesalahan diksi dari segi konotasi}

(1) Badan Pengawas Daerah (BKD) Pemprov Sumut Kaiman Turnip mengatakan mereka tengah melakukan jemput bola ke pengadilan meminta salinan putusan terhadap 33 ASN mantan koruptor. (TM, Hal 9. 01/12/2018).

Analisis Data :

$$
\text { Pada kalimat }
$$

Penggunaan diksi yang kurang tepat dalam kalimat pada berita di atas adalah kata jemput bola.Kata jemput bola merupakan kata yang mengandung makna konotasi. Kata jemput bola sebaiknya diganti dengan kata sesuatu untuk mengambil data. Kata jemput bola pada kalimat ini bukan yang bermakna menjemput bola ke dalam gawang. Tetapi maksud kata jemput bola dalam kalimat diatas merupakan kata sesuatu untuk mengambil data. Dengan demikian kalimat yang benar adalah :

Badan Pengawas Daerah (BKD) Pemprov Sumut Kaiman Turnip mengatakan mereka tengah melakukan sesuatu untuk mengambil data ke pengadilan meminta salinan putusan terhadap 33 ASN mantan koruptor.

(2) Ketua Relawan Badan Pemenangan Prabowo Sandiaga Uno (PADI Sumut) Sugiat Santoso mengemukakan keyakinananya, arah angin berpihak kepada calon Presiden dan calon wakil Presiden nomor urut 02 tersebut. (TM, Hal 5. 04/12/2018).

Analisis Data : 


$$
\text { Pada kalimat }
$$

Penggunaan diksi yang kurang tepat dalam kalimat di atas adalah kataarah angin. Kara arah anginmerupakan kata yang mengandung makna konotasi. Kata arah angin sebaiknya diganti dengan kata suatu keberuntungan. Kata arah angin dalam kalimat ini bukan yang bermakna arah angin berarah kepada kita. Tetapi arah angin dalam kalimat di atas merupakan kata suatu keberuntungan. Dengan demikian kalimat yang benar adalah:

Ketua Relawan Badan Pemenangan Prabowo Sandiaga Uno (PADI Sumut) Sugiat Santoso mengemukakan keyakinanannya, suatu keberuntungan akan berpihak kepada calon Presiden dan calon wakil Presiden nomor urut 02 tersebut.

\section{b. Kesalahan diksi dari segi bersinonim}

(1) Ketiganya disangkakan sebagai penerima suap. Dua orang lainnya disangkakan sebagai pemberi suap, yakni advokat atau pengacara Arif Fitrawan dan tahanan kasus pidana umum bernama Martin P Silitonga. (TM, Hal. 7. 01/12/2018).

Analisis Data :

Pada kalimat

Penggunaan diksi yang kurang tepat dalam kalimat di atas adalah kata disangkakan. Penggunaan kata disangkakantidak tepat untuk kalimat tersebut. Kata disangkakan dan kata diduga merupakan dua kata yang bersinonim dalam arti mempunyai makna yang sama. Kata disangkakan sebaiknya diganti dengan kata diduga. Karena kata disangkakan memiliki arti yang belum pasti, dan memiliki makna yang belum jelas. Tetapi kata diduga memiliki makna yang lebih jelas apabila disambungkan pada kalimat selanjutnya. Dengan demikian kalimat yang benar adalah :

Ketiganya diduga sebagai penerima suap. Dua orang lainnya yang didugasebagai pemberi suap, yakni advokat atau pengacara Arif Fitrawan dan tahanan kasus pidana umum bernama Martin P Silitonga.

(2) Atasan putusan KPU itu, OSO melayangkan gugatan ke Mahkamah Agung (MA) 
dan pengadilan Tata Usaha

Negara (PTUN). (TM, Hal 2.

01/12/2018).

Analisis Data :

$$
\text { Pada kalimat }
$$

Penggunaan diksi yang kurang tepat dalam kalimat di atas adalah kata melayangkan gugatan. Penggunaan kata melayangkan gugatan tidak tepat dalam kalimat tersebut. Kata melayangkan gugatan dan kata mengajukan gugatan merupakan dua kata yang bersinonim dalam arti mempunyai makna yang sama. Kata melayangkan gugatan sebaiknya diganti dengan kata mengajukan gugatan. Kata melayangkan gugatan pada kalimat ini bukan yang bermakna gugatan melayang atau terbang. Tetapi kata melayangkan gugatan dalam kalimat ini merupakan kata mengajukan gugatan. Dengan demikian kalimat yang benar adalah :

Atasan putusan KPU itu, OSO mengajukan gugatanke Mahkamah Agung (MA) dan pengadilan Tata Usaha Negara (PTUN).
2. Kesalahan Penggunaan Diksi Berita Politik dalam Harian Tribun Medandari Segi Kecermatan Pilihan Diksi

a. Kesalahan diksi dari segi pemakaian kata yang tidak ekonomis

(1) Hakim mengatakan, selama dua tahun setelah Ahmadi menjalani pidana pokoknya, ia tidak boleh menggunakan hak pilihnya. (TM, Hal 2. 04/12/2018).

Analisis Data :

Pada kalimat (1) Hakim mengatakan, selama dua tahun setelah Ahmadi menjalani pidana pokoknya, ia tidak boleh menggunakan hak pilihnya. Penggunaan diksi dalam kalimat tersebut tidak tepat. Kata pokoknya sebaiknya dihilangkan karena mengandung ketidakjelasan makna dalam kalimat tersebut. Kita harus memilih kata yang tepat dan ekonomis. Kata pokoknya dalam kalimat tersebut membuat kalimat menjadi kurang efektif, karena adanya penggunaan kata yang tidak ekonomis. Penggunaan struktur tidak ekonomis ditandai oleh penggunaan struktur yang 
berpanjang-panjang atau berbelitbelit. Dengan demikian kalimat yang benar adalah :

Hakim mengatakan, selama dua tahun setelah Ahmadi menjalani pidana, ia tidak boleh menggunakan hak pilihnya.

(2) Tetapi minggu depan KTP sudah dibisa diambil di kantor disdukcapil Sumut, ujar Ismail yang ditemui di lokasi kegiatan. (TM, Hal 9. 06/12/2018).

Analisis Data :

Pada kalimat (2) Tetapi minggu depan KTP sudah dibisa diambil di kantor disdukcapil Sumut, ujar Ismail yang ditemui di lokasi kegiatan. Penggunaan kata dalam kalimat tersebut tidak tepat. Kata dibisa sebaiknya dihilangkan karena adanya penggunaan kata yang tidak ekonomis dan berbelitbelit. Sehingga kata dalam kalimat tersebut menjadi kurang efektif dan makna dalam kalimat tersebut tidak jelas disampaikan. Kita harus memilih kata yang tepat dan ekonomis. Dengan demikian kalimat yang benar adalah:

Tetapi minggu depan KTP sudah bisa diambil di kantor disdukcapil Sumut, ujar Ismaail yang ditemui di lokasi kegiatan.

\section{b. Kesalahan diksi dari segi pemakaian kata yang mubazir}

(1) Ia mengklaim, tidak hadir dalam persidangan dan rapatrapat di DPD RI bukan tanpa alasan. Pasalnya, ia tak mengakui kepemimpinan Oesman Sapta Odang (OSO) dan beberapa rekannya di DPR RI. (TM, Hal 2. 22/12/2018).

\section{Analisis Data :}

Pada kalimat (1) Ia mengklaim, tidak hadir dalam persidangan dan rapat-rapat di DPD RI bukan tanpa alasan. Pasalnya, ia tak mengakui kepemimpinan Oesman Sapta Odang (OSO) dan beberapa rekannya di DPR RI. Penggunaan kata rapat-rapat dalam kalimat tersebut tidak tepat. Penambahan kata rapat-rapat mengandung penggunaan unsur yang mubazir. Kemubaziran itu ditandai oleh penggunaan kata yang diulangulang. Sebaiknya kata rapat-rapat tidak perlu diulang-ulang. Dengan demikian kalimat menjadi benar adalah : 
Ia mengklaim, tidak hadir

dalam persidangan dan rapat di

DPD RI bukan tanpa alasan.

Pasalnya, ia tak mengakui

kepemimpinan Oesman Sapta
Odang (OSO) dan beberapa rekannya di DPR RI. Maka dapat dideskripsikan data ke dalam tabel deskripsi dibawah ini :

Tabel1

Tabel Data Kesalahan Penggunaan Diksi Berita Politik dalam Harian Tribun Medan dari Segi Ketepatan Diksi

\begin{tabular}{|c|c|c|c|}
\hline No. & Bentuk Kesalahan & Frekuensi & Presentase \\
\hline 1. & Kata bersinonim & 21 & $56,75 \%$ \\
\hline 2. & Kata konotasi & 16 & $43,24 \%$ \\
\hline 3. & Kata yang mirip ejaannya & & \\
\hline 4. & Kata-kata ciptaan sendiri & & \\
\hline 5. & Kata akhiran asing & & \\
\hline 6. & Kata idiomatic & & \\
\hline 7. & Kata umum dan kata khusus & & \\
\hline 8. & Kata indria & & \\
\hline 9. & Perubahan makna & & \\
\hline 10 & Kata kelangsungan pilihan kata & & \\
\hline & Total & 37 & $99,99 \%$ \\
\hline
\end{tabular}

Dari data deskripsi di atas disimpulkan bahwa, kesalahan penggunaan diksi dari segi ketepatan diksi yang paling dominan adalah kesalahan diksi dari segi bersinonim dengan persentasenya mencapai 55,75\%, dan yang paling rendah adalah kesalahan diksi dari segi konotasi dengan persentasenya mencapai 43 , $24 \%$. 
Tabel 2

Tabel Data Kesalahan Penggunaan Diksi Berita Politik dalam

HarianTribun Medandari Segi Kecermatan Pilihan Diksi

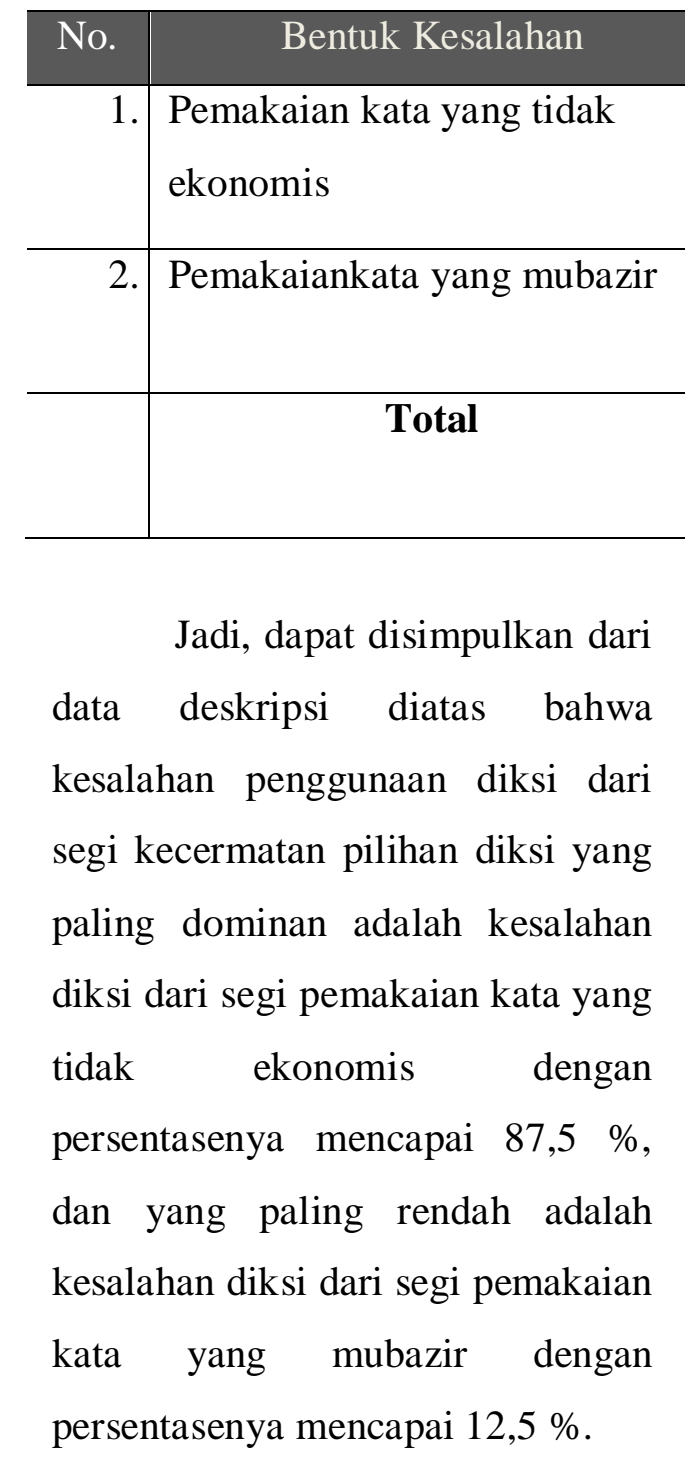

\title{
PENUTUP
}

\section{A. Simpulan}

Berdasarkan dari hasil pembahasan yang dilakukan dalam penelitian ini, maka dapat disimpulkan bahwa :

\section{Frekuensi}

Presentase

7

|

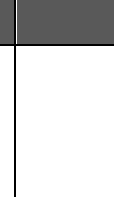

\author{
$87,5 \%$
}

$12,5 \%$

\begin{tabular}{|l|c}
\hline 1 & $12,5 \%$ \\
\hline $\mathbf{8}$ & $\mathbf{1 0 0} \%$ \\
\hline
\end{tabular}


bagi penulis khususnya dan bagi pembaca pada umumnya. Serta dapat memberikan ilmu mengenai materi yang dibahas dalam skripsi ini. Penulis sadar penyusunan skripsi ini masih banyak kekurangan dan jauh dari kesempurnaan.

Sehubungan dengan hal di atas, maka disarankan kepada para konsumen linguistik khususnya pada bidang diksi, baik mahasiswa, peneliti selanjutnya, maupun guru kebahasaan, memperhatikan dengan seksama tentang penggunaan diksi yang tepat, kecermatan penggunaan diksi dalam kalimat. Maka dari itu, hasil penelitian ini kiranya mampu menjadi satuan tulisan ilmiah yang dapat dimanfaatkan oleh para konsumen linguistik untuk dijadikan sebagai sumber referensi atau pada materi bandingan mengenai penggunaan diksi.

\section{DAFTAR PUSTAKA}

Badudu. J.S. 1985. Inilah Bahasa

Indonesia yang Benar. Jakarta : PT Gramedia

Keraf, Gorys. 2001. Diksi dan Gaya

Bahasa. Jakarta: PT

Gramedia Pustaka

Utama.

Luimintatang. 1988. Bahasa
Indonesia Ragam Lisan

Fungsional Bentuk Dan

Pilihan Kata. Jakarta.

Dapartemen Pendidikan dan

Kebudayaan.

Moleong, Lexy J. Prof. Dr. M.A, 2012, Metodologi Penelitian Kualitatif (Edisi

Revisi). Bandung: PT Remaja Rosdakarya.

Silalahi, Vebrin. 2012.

Ketidaktepatan Penggunaan Diksi Atau Kata Pada Rubrik Pumpunan Harian Sinar Indonesia Baru Terbitan September 2011. Skripsi. Universitas Negeri Medan. 